\title{
Experiences of families in the Immunization of Brazilian Children Under Two Years Old
}

\author{
Glória Lúcia Alves Figueiredo ${ }^{1}$ \\ Juliana Coelho Pina ${ }^{2}$ \\ Vera Lúcia Pamplona Tonete ${ }^{3}$ \\ Regina Aparecida Garcia de Lima ${ }^{4}$ \\ Débora Falleiros de Mello ${ }^{5}$
}

This study aimed to describe the experience of families in the immunization of children under two years. Descriptive study with qualitative data analysis. Twenty-two subjects participated in unstructured interviews. Results were grouped into three categories: Practical knowledge on children's immunization; Responsibility and compulsory immunization of children; Increasing the scope of children's immunization practices. The findings highlight factors that increase vaccination rates: experience and personal fulfillment in maternity, fear of getting ill, recognizing it as good care, access, schedule flexibility, dissemination, immunization record card, immunization campaigns and availability of vaccines, and factors that increase non-vaccination rates: parent's inexperience, refusal to apply simultaneous immunization, fragmented care, absence of dialog, discrimination, false counter-indications and compulsoriness. Immunization centered on compliance with the calendar or in authoritarian situations is not tied to family care. The bond between health care professionals and families needs to be strengthened to increase the participation in child health protection and promotion measures.

Descriptors: Child Health (Public Health); Immunization; Primary Health Care.

\footnotetext{
${ }^{1}$ RN, Ph.D. in Nursing. Professor, Universidade de Franca, SP, Brazil. E-mail: enfermagem@unifran.br.

2 RN, Escola de Enfermagem de Ribeirão Preto, Universidade de São Paulo, WHO Collaborating Centre for Nursing Research Development, SP, Brazil. E-mail: jcoelho@eerp.usp.br.

${ }^{3}$ RN, Ph.D. in Nursing. Assistant Professor, Faculdade de Medicina de Botucatu, Universidade Estadual "Paulista Júlio de Mesquita Filho", SP, Botucatu, Brazil. E-mail: vtonete@uol.com.br.

${ }^{4}$ RN, Ph.D. in Nursing. Full Professor, Escola de Enfermagem de Ribeirão Preto, Universidade de São Paulo, WHO Collaborating Centre for Nursing Research Development, SP, Brazil. E-mail: limare@eerp.usp.br.

${ }^{5}$ RN, Ph.D. in Nursing. Associate Professor, Escola de Enfermagem de Ribeirão Preto, Universidade de São Paulo, WHO Collaborating Centre for Nursing Research Development, SP, Brazil. E-mail: defmello@eerp.usp.br.
}

Corresponding Author:

Débora Falleiros de Mello

Universidade de São Paulo. Escola de Enfermagem de Ribeirão Preto

Departamento Materno-Infantil e Saúde Pública

Av. dos Bandeirantes, 3900

Bairro: Monte Alegre

CEP: $14040-902$ Ribeirão Preto, SP, Brasil

E-mail: dfmello@eerp.usp.br 


\title{
Experiências de famílias na imunização de crianças brasileiras menores de dois anos
}

O objetivo foi descrever as experiências de famílias sobre imunização de crianças menores de dois anos. É estudo de natureza descritiva, com análise qualitativa dos dados, entrevistas não estruturadas com 22 sujeitos. Os resultados foram agrupados em: conhecimentos práticos sobre imunização, responsabilidade e obrigatoriedade na imunização e ampliação da prática de imunização. Foram destacados elementos que fortalecem a imunização: experiência e realização pessoal no papel de ser mãe, temor de adoecimento, reconhecimento como um bom cuidado, acesso, flexibilidade do horário, divulgação, cartão de vacinas, campanhas de vacinação e disponibilidade de vacinas, e elementos da não imunização: inexperiência dos pais, recusa de aplicações simultâneas de vacinas, assistência fragmentada, ausência de diálogo, discriminação, falsas contraindicações e obrigatoriedade. A imunização centrada no cumprimento do calendário vacinal, ou em situações autoritárias, está descolada do cuidado familiar. 0 vínculo com as famílias precisa ser fortalecido para ampliação da adesão às medidas de proteção e promoção da saúde da criança.

Descritores: Saúde da Criança; Imunização; Atenção Primária à Saúde.

\section{Experiencias de familias en la inmunización de niños brasileños menores de dos años}

\begin{abstract}
El objetivo fue describir las experiencias de familias sobre inmunización de niños menores de dos años. Estudio de naturaleza descriptiva, con análisis cualitativa de los datos, entrevistas no estructuradas con 22 sujetos. Resultados agrupados en: Conocimientos prácticos sobre inmunización, Responsabilidad y obligatoriedad en la inmunización, Ampliación de la práctica de inmunización. Fueron destacados elementos que fortalecen la inmunización: experiencia y realización personal en el papel de ser madre, temor a enfermarse, reconocimiento como un buen cuidado, acceso, flexibilidad del horario, divulgación, cartón de vacunas, campañas de vacunación y disponibilidad de vacunas, y elementos de la no-inmunización: inexperiencia de los padres, recusa de aplicaciones simultáneas de vacunas, asistencia fragmentada, ausencia de diálogo, discriminación, falsas contra-indicaciones y obligatoriedad. La inmunización centrada en el cumplimiento del calendario vacunal o en situaciones autoritarias está desvinculada del cuidado familiar. El vínculo con las familias precisa ser fortalecido para ampliación de la adhesión a las medidas de protección y promoción de la salud del niño.
\end{abstract}

Descriptores: Salud del Niño; Inmunización; Atención Primaria de Salud.

\section{Introduction}

Historically, immunization in children has been successful in several countries, through high vaccine coverage and considerable advances in the control and eradication of diseases.

The World Health Organization designed the Expanded Program on Immunization (EPI) in the 1970s, aiming to reduce the morbidity and mortality of six diseases preventable by immunization: measles, whooping cough, polio, tuberculosis, tetanus and diphtheria, through the application of their corresponding

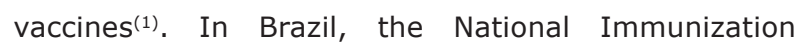
Program (NIP) was institutionalized in 1975, aiming to coordinate immunization actions developed in the Brazilian service network ${ }^{(1-2)}$.

Vaccination is a routine action in primary health care services, with great influence on children's general 
health conditions. It represents an expressive health technology advance in the last decades and is considered a good cost-effectiveness procedure in the health sector $^{(3)}$. To broaden the targets of any immunization program, it is necessary to manage the vaccines properly at the right time and with a practice that requires effective efforts from health professionals, related with changes in attitudes and beliefs about immunization(4). The more the vaccination is integrated into child care, in the process of growth and development, the more successful the vaccination will be as an indicator of vaccine coverage, also contributing to enlarge families' understanding about this health action.

International studies show the relevance of nursing practice for the success of child immunization ${ }^{(4-7)}$. Immunization practices are varied and include technical acts as well as relational, organizational and continuing education activities ${ }^{(5)}$. Decisions about childhood immunization are not easy for parents and it was crucial for healthcare professionals to give parents updated information and encourage them(6). Despite understanding the importance of immunization, parents often have multiple responsibilities that preclude them from remembering their child's vaccination schedule ${ }^{(4)}$. Immunization of babies and children depends upon initiative from their adult caregivers, many of whom may be highly anxious about the safety of immunizations, or anxious about subjecting their children to painful procedures $^{(7)}$. Nurses need to build good relationships and practical partnerships with parents/caregivers.

A bibliographical survey in a Latin American journal verified little scientific production about families' experience in daily care regarding child immunization, and the theme deserves further research.

The understanding of health practices, both in the services and in the families, needs to be reconsidered with a view to enhanced bonding with the population and understanding adherence to health protection and promotion measures, the effective activity of health professionals with the subjects and the construction of accountability plans and health projects ${ }^{(8)}$. Health and disease experiences are important to health care and the way people deal with health problems and/or recommendations facilitate in meeting and reproducing solutions and propositions according to the knowledge experienced in practice. In this sense, it is important to know what families think about child immunization, as it can assist in expanding nursing care in child health with families. Thus, this study aims to describe the experiences of families in the immunization of children under two years old, based on Brazilian families' reports.

\section{Methods}

This is a descriptive study with qualitative data analysis.

The research was developed at two Basic Health Units (BHU) with a large number of children who access medical care and a high demand for vaccination. Families' inclusion criteria were: having a child under two years old, living in the coverage area of the selected health units, following-up child health at the selected health units, mother or caregiver staying at home with child most of the time. Based on these criteria, 84 families were found. Of these, 34 changed their address, 19 had incorrect addresses and 12 were not found at their homes after three home visit attempts. Thus, nineteen families participated in this research, nine from $\mathrm{BHU} A$ and ten from BHU B. Twenty-two subjects participated in the interviews, i.e. 17 mothers, 04 fathers and 01 maternal grandmother, who were identified by codenames.

Non-structured interviews were recorded with participants, which started with the following guiding question: How have children's care and immunization been developed? Along the interview, the researchers intended to talk to participants about their children's immunization, how they have learned about immunization and what they know about it, what they think about families who do not regularly attend health services to vaccinate children, and whether they had suggestions to approximate families and public health services. Attempts were made to apprehend the families' narrative, trying to get to know their experiences, concerns, responsibilities, needs and decision making for children's healthcare, especially regarding immunization.

The empirical data produced from the interviews was transcribed and organized into individual files. Data analysis followed the steps recommended in thematic content analysis, that is, pre-analysis (reading the empirical material seeking to map the meanings the subjects attributed to the questions posed); analysis of the expressed and latent meanings (identification of units of meaning), elaboration of the themes (synthesis of the empirical data) and final analysis (discussion of the themes). After transcribing the interviews, readings, ordination and skim reading ${ }^{(9)}$ were performed during data analysis. In this study, the empirical material was not statistically analyzed, as originally advocated by the technique, but treated in a comprehensive way, seeking to discover what was behind the manifested content ${ }^{(10)}$.

Data were organized and structured in parts to identify aspects that were repeated and highlighted 
and to apprehend relevant ideas, that is, key ideas and meanings of the families' experiences on the immunization of children, leading to the grouping of data in three themes: Practical knowledge on children's immunization; Responsibility and compulsory immunization of children, and Increasing the scope of children's immunization practices.

The interviews were carried out in the households. The research was approved by the Research Ethics Committee, in line with standards and recommendations for research involving human beings.

\section{Results}

\section{Practical knowledge on children's immunization}

Under this theme, the aspects of the importance of the vaccination card, vaccination associated with prevention of diseases, the importance of the follow-up and of vaccination campaigns, maternal and caregivers' feelings, and the effects of post-vaccination are presented.

Families highlight the vaccination card as a source of knowledge about the vaccines that the child needs.

As soon as the child is born, leaves the hospital, leaves with all those papers, with registration, with dates scheduled to take to the BHU to have the heel prick test done. And at the $\mathrm{BHU}$ people advise us. They give you the card, the day you have to take the child again to get the vaccine. There is no way out, just have to go (father - T Family).

When I had him, they gave me the immunization card and I said: Ah! I'm gonna take him to get the vaccine because it is the best for my son. The card tells you to get the vaccination (mother - P Family).

Having and using the immunization card seemed to help families in decision making on their children's immunization. The I mmunization card is an instrument not only to remind them of the vaccination return for the follow-up of children, but also a guarantee of the right to immunization provided by health services.

According to the reports, at the moment of immunization, orientation was summarized in the immunization card, with the appointment. There were no reports of orientation regarding the importance of immunization, or even regarding which vaccine children received or would receive on the next return visit.

In the following reports, aspects appear related to immunization associated to prevention of diseases, which express the awareness of families regarding this action.

We have to prevent the disease, have to vaccinate. They say that there was no immunization in the past, and people got childhood paralysis, problems in the legs, arms. So, I know people who, maybe, it was because they did not get the vaccine. Now, today, vaccines are there to avoid these kinds of things There is yellow fever, flu. What about the remorse later? (mother - P Family).

The vaccine is a concern. I had, the other day, I went to the farm and forgot about the immunization campaign. It was already late when I remembered: Will I be able to go there at the BHU and they'd give the vaccine? What about the other one? Will I? I stayed up all night, thinking, so on the other day I'd leave. Then, on the other day, I was afraid of death, afraid of the childhood paralysis, you know? Because, can you imagine one of my children with childhood paralysis? My fault, right? (mother-A Family).

Families attributed good care to immunization, able to protect children from diseases, but with the condition of taking all recommended doses and on the date scheduled in the current immunization calendar.

In the following, aspects regarding returns to the regular immunization calendar, immunization campaigns and delays were reported.

I take the child to be vaccinated at $\mathrm{BHU}$ and also when there is a campaign. They give it at the Community Center. Then I take him because it is closer. The place is really easy, it is here on the street down there (mother -X Family).

It is delayed because I pity him, and then he gets too cranky, and I don't have anybody to leave him with if I need to get out. It doesn't help sending me letters, I can't take him there. I take him on the campaigns (mother - F Family).

The strategy of vaccination campaigns was considered a health practice structured around a common basis: place (easy access), good dissemination and one day to get the vaccine (extended work hours). Among the interviewed families, some were delayed with vaccines, but did not perceive themselves as absent.

Maternal and caregivers' feelings were also reported, like in the following examples:

They call us, but they don't know how it is. Who is going to take care of him for me? But, then I go there, it is not to give everything at once, no. It makes the child suffer a lot. I can't take it, to see that much of needles. And then, it is even worse, when we have to take care (mother - F Family).

There's a lot of vaccines in the first year. It starts with that BCG. Like, I think that, it is something that makes us feel sorry for them, this thing of applying a needle in the child, you know? But if she has to go through it and it is good for them (grandmother - I Family)

Among the interviewed families, the pain related to the immunization entailed antagonist interpretations. In one case, it appeared as something that must be faced, 
and in another it was considered a condition that causes disruption.

The occurrence and management of expected or adverse post-immunization events in children were also reported.

Now you have to take him to vaccinate again. It gives fever, but you have to. Then, I give some tea, the way the doctor advised me, and the mother says: you have to give a mint or herbal tea with some drops of dipyrone. Then I put it in the tea and give it to him and the fever improves. Ah! I also give him a bath, put on few clothes. Vaccines are not bad! We mothers know we have to do good for the child (mother - P Family).

They have nothing, give them the vaccine, give them the injection. Jesus! It gets on their whole body. It gets all sore. Yet, there is fever, also... You have to prevent, right? Sometimes there are diseases and to prevent it is through vaccines, I give him the vaccine after lunch, because in the morning, we suffer (laugh). He has fever, sore body, depending on the way and on the spot, we get him on the lap, it is going to hurt. Then, when it is on the arm, you have to avoid taking him there. When it is on the butt, we have to put him with the butt upside so as not get on the vaccine (mother - S Family).

The immunization entailed the need to face associated problems. Families, in general, showed knowledge regarding the need for special care with children after vaccination.

When reporting the ways they participated in the children's care, relatives became valued as parents and caregivers, although they appointed the need for technical support for this care. Then, nursing can contribute with health education, prevention and intervention.

\section{Responsibility and compulsory immunization of children}

Under this theme, the reports that show the characteristics of the obligatory immunization and missed opportunities in some situations are presented.

In the past there weren't these vaccines. Today there is and we don't recognize it. It's the mother's fault, you know? Because the nurse and vaccine, all right. It's just the mother's fault, really, who doesn't have time, responsibility (mother - L Family).

The mother is obliged to vaccinate the child. It is good for him. I mean, nobody obliged me, I think it is the mothers' obligation. As the child is born, they already give you the card (mother - P Family).

I think it's a mistake. I don't know what to think. Because, as they say, each case is different. There are mothers who, sometimes, don't bring because of lack of resources, sometimes, lack of information. Or because, don't know, don't want. I think it's really important to take care (mother - N Family).

Families who used health services reported comparisons with a period in which there were fewer vaccines and few health professionals, indicating that they see differences over time, because of more information, higher number of health professionals and vaccines available. However, the participation of health services is restricted to the "letters" that communicate the delay in the vaccination and summon families to attend the health services in order to update the vaccines. The reports suggest that health services are little organized to share families' doubts, concerns and difficulties regarding care.

The obligation was outlined under different aspects. In one of them, it was perceived through the health services booklets. In the other, it was constructed in daily life, in the observation of sequelae in children who had not been vaccinated. Prevention appeared as a responsible act in family care for the children, especially in the mother-child relation.

Lost immunization opportunities were reported by the interviewed families, like in the following examples:

I've never left, like, sometimes, would get a little late, I would not go to the health unit, but never would be delayed for more than 20, 30 days. Sometimes he has fever, flu. Then, I don't give it to him! Because besides the cold, take care with the fever, with pain and sore throat, he's already feeling, the vaccine, sometimes, there're reactions. They cry like 24 hours. Then, I don't give it! They already have a problem, will give injection, there'll be another problem. You'd worsen things. Then, I don't allow it! (mother - S Family).

He gets too sick, C. has bronchitis, he always has to take medications. It doesn't help sending me those letters, can't take him. I take him on the campaigns. The doctor said not to vaccinate because he already had fever. Had to wait to finish the medication, but he never stops taking medications, I got afraid. They call us, but they don't know how it is. Who is going to take care of him for me? (mother - F Family).

The vaccination delay brought different meanings for the families, generally attributed to the mother: irresponsibility, lack of time, children's dependency, lack of awareness and guidance. It is inferred from the reports that responsibility for vaccination, although attributed to the mother, permeates the family context.

Non-attendance to immunization seemed to establish disposition to blame. Thus, if for any reason children got sick or were affected by non-vaccination, one person would be guilty. 


\section{Increasing the scope of children's immunization} practices

Under this theme, suggestions to reach families who do not attend the vaccination are presented, as the reports show:

Campaign everybody does. There are warnings on TV. I think there should be some program, people go to the houses, follow up, and know why the mother does not bring the child. Because not all who do not bring, do not because they don't want to, sometimes there is some problem and they can't bring the child (mother - J Family).

I think it's an awareness work, really. But also to use this awareness work through a social worker, at the church. I'd like, kind of, schedule a day, a Saturday and someone from the health area and give a speech to people. I see that many people are misinformed, and there're others who don't want be informed (father - T Family).

I think that only the letter, people see it, read and don't give a damn, right? Then, if somebody came, to talk and explain, it would be important to have a follow up (mother - X Family).

Families highlight communication media, the follow up of child health, the participation of other professionals and other social sectors to increase immunization in childhood.

Following child and family health, and especially knowing the health conditions and lifestyles, and the reasons why families do not attend health services are essential to expand health activities and promote health to families and community.

\section{Discussion}

Vaccination, as important care to protect children's health, implies articulation among the family, health service and community. The involvement and responsibility of all would make it difficult to lose immunization opportunities.

An study about vaccination determinants regarding the health system verified that it is important to observe children's and families' characteristics, family size, place of residence, child's age, schooling of family head, the availability and access to the vaccination room, information about the programs and health service hours, checking the barriers that should be assessed and solved and the lack of information for the population(11).

A study addressing issues about vaccination delay, which interviewed families, shows that an expressive number of them did not receive orientations about the administered vaccine, the reactions and the date of the next vaccine, concluding that the reason of the delay in vaccination and the non-vaccination are more related to the health services' characteristics than to populations'(12). Another study about parents' difficulties to decide about vaccinating the children or not shows the fear and preoccupation with the risks of the vaccines, and in the group of parents in which children's vaccination is incomplete, there is less confidence in the information health professionals provided(6).

The receptivity of a service performed basically by nursing could be a favorable moment for the establishment of good communication between nursing and the clientele. Nursing care to children at a basic health unit implies the (re) construction of a health practice with relations of proximity, welcoming, facilitating interaction and effective educative actions ${ }^{(13)}$. Childhood immunizations require collaboration with parents, communication skills and rapport, which are core to nursing work $^{(7)}$.

Association between larger immunization coverage and residence close to immunization places was found in studies on immunization coverage, difficulty or lack of access to health services and transportation as a cause $^{(14)}$.

One of the reasons for incomplete vaccination coverage is the contraindications for immunization provided by health professionals(6). A prior study ${ }^{(15)}$ has evidenced that parents' decision to decline the immunization of their children is linked to a conscious decision. Authors recommend ready access to evidencebased information on immunization, articulated with parents' questions, doubts and beliefs, stating the importance of building and maintaining the confidence of families, as well as to provide accurate information.

Studies show that the growing supply of vaccines is viewed as a burden of pain, anguish and adverse events that interfere in family acceptance and aggravate antiimmunization feelings ${ }^{(6,16)}$.

In ethical terms, it is the patients' right to have access to any information regarding their body, disease, treatments, etc., and also because knowledge enhances the efficacy of cure. Thus, both in individual or group care and in health programs, it would be essential to consider knowledge transmission by health professionals an indispensable task, which would increase patients' autonomy and reinforce their condition of social subjects, able of self care and demanding that institutions attend to their needs ${ }^{(17)}$, including children's vaccination.

Immunization protects the vaccinated person and the community, and the form of implementing this protection varies from country to country, but all have 
their regular vaccination calendar ${ }^{(18)}$. Each missed dose of vaccine was associated with increased risk of disease, with delay in the third dose conferring the greatest risk $^{(6)}$. Thus, it is important that any infant receives a complete series of a particular vaccine in time. Not only are individual children at risk if vaccination is delayed, but epidemics ${ }^{(4)}$.

The development of the Immunization Program in Brazil aims for a great extent of vaccination coverage to reach an adequate level of immunization. However, the occurrence of unnecessary counter-indications, based on obsolete theories or concepts, is observed, with consequent loss of immunization opportunities, compromising vaccine coverage ${ }^{(19)}$.

Health professionals' attitudes and conducts with families of children absent from the vaccine calendar have to be reviewed, because this condition, loaded with prejudices, confers a negative image to the family and hinders its acknowledgement. Families are not having the opportunity to share difficulties they face in the child's care. This mistake, able to distance families and health services, seems to cross practices, hindering and compromising prevention.

The use of immunobiological agents raises ethical issues and the approach to deal with it is not by imposition, but through education, to allow people to choose consciously, analyzing the importance of vaccination for health promotion(20). Health education and articulation with organizations in the community, governmental or not, have been appointed as the first steps for more extensive actions in solving health problems ${ }^{(2)}$.

It is important to understand that the relations between families and health services are inserted in a set of social, political and economic determinants, and that lifestyle can influence prevention of the most varied diseases and health promotion. However, this integration will depend on the parents' enthusiasm and dedication in daily life in the growth and development process of children, and on health professionals in recognizing and interviewing about their anguish, needs, abilities and difficulties, respecting and motivating them(21).

Immunization is a preventive action the health service offers to the population and it is essential to expand nursing activities directed at the child and family, implying that they should be close in the health-disease process and care, because the child and the family need several kinds of health care, whatever the fragility or harm is ${ }^{(22)}$.

The bond between health care professionals and families needs to be strengthened to increase adherence to child health protection and promotion measures.

\section{Conclusion}

Families answer questions about childhood vaccination practice with several aspects: with the immunization card, as prevention means, vaccination campaigns, pre and post-vaccination care and absence from the health service to update the vaccines.

The elements increasing immunization were identified: experience and personal fulfillment in maternity, fear of diseases, acknowledge good care, knowledge, access, flexible hours, dissemination, gratuitousness, immunization card, vaccination campaigns, availability of vaccines and health professionals. The elements that increase nonimmunization are: parents' inexperience, excess of tasks, refusal of simultaneous application of vaccines, fragmented care, lack of dialogue, discrimination, false counter-indications and compulsoriness.

Immunization, in health programs and governmental guidelines, is valued for individual and collective protection and is considered an important public health practice. It is evident that, in an emergency, the important thing is to create collective immunity, improving coverage and efficacy. However, in terms of sustainability, over time, other aspects emerge. For example, if the vaccination is complied with based on the calendar or in very authoritarian situations, it is detached from family care practice and its sustainability tends to become fragile.

Health professionals need to hear and explore the particular concerns and fears of families about immunization and provide specific and tailored responses to these.

Vaccination practice can become strongly sustainable and longitudinal in the form of a more integrating care, able to articulate technical intervention with other nontechnological aspects, expand professional attitudes supported by families' knowledge, respecting fragilities, seeking the understanding of different situations and approximating families to health services, generating new relations and allowing for new possibilities of public health practice to reduce the risk of missed immunization opportunities.

\section{References}

1. Ministério da Saúde (BR). Programa Nacional de Imunizações: 30 anos. Brasília: Ministério da Saúde, Secretaria de Vigilância em Saúde; 2003. 212 p.

2. Ministério da Saúde (BR). Manual de procedimentos para vacinação. Brasília: Fundação Nacional de Saúde; 2001. 72 p. 
3. Guimarães TMR, Alves JGB, Tavares MMF. Impacto das ações de imunização pelo Programa Saúde da Família na mortalidade infantil por doenças evitáveis em Olinda, Pernambuco, Brasil. Cad Saúde Pública. 2009;25(4):868-76.

4. Joyce C. Steps to success: getting children vaccinated on time. Pediatr Nurs. 2007;33(6):491-6.

5. Petit G, Lettelier M, Gauvin L, Boulianne N, Valiquette L. The immunization practices of nursing staff in local community health centers. Can J Public Health. 2007;98(4):311-7.

6. Austin H, Campion-Smith C, Thomas S, Ward W. Parents' difficulties with decisions about childhood immunization. Community Pract. 2008;81(10):32-5.

7. Plumridge E, Goodyear-Smith F, Ross J. Nurse and parent partnership during children' vaccinations: a conversation analysis. J Adv Nurs. 2009;65(6):1187-94.

8. Ayres JRCM. Hermenêutica e humanização das práticas de saúde. Ciênc Saúde Colet. 2005;10(3):549-60.

9. Minayo MCS. O desafio do conhecimento: pesquisa qualitativa em saúde. São Paulo: Hucitec; 2006. 406 p. 10. Gomes R. Análise e interpretação de dados de pesquisa qualitativa. In: Minayo MCS, organizadora. Pesquisa social: teoria, método e criatividade. Petrópolis (RJ): Vozes; 2007. p. 79-108.

11. Acosta-Ramirez N, Durán-Arenas LG, Eslava-Rincón JI, Campuzano-Rincón JC. Determinants of vaccination after the Colombian health system reform. Rev Saúde Pública. 2005;39(3):421-9.

12. Molina AC, Godoy I, Carvalho LR, Caldas AL Junior. Childhood immunization status, and individual and family characteristics in the interior of São Paulo. Acta Scient Health Sci. 2007;29(2):99-106.

13. Figueiredo GLA, Mello DF. O cuidado de enfermagem às crianças menores de dois anos de idade em uma Unidade Básica de Saúde: utilizando os momentos da vacinação. Acta Paul Enferm. 2003;16(4):86-90.

14. Paterson J, Percival $T$, Butler $S$, Williams $M$. Maternal and demographic factors associated with nonimmunization of Pacific infants living in New Zealand. $\mathrm{N}$ Z Med J. 2004;117(1199):994-1001.

15. Hilton S, Petticrew M, Hunt K. Parents' champion vs. vested interests: who do parents believe about MMR? A qualitative study. Biomed Central Public Health. [internet]. 2007,7:42 [acesso $10 \mathrm{fev}$ 2011]. Disponível em: http://www.biomedcentral.com/1471-2458/7/42.

16. Logullo P, Carvalho HB, Saconi RA, Massad

E. Factors affecting compliance with the measles vaccination schedule in a Brazilian city. São Paulo Med J. 2008;3(1):166-71.
17. Campos WSC. Reforma da reforma: repensando a saúde. São Paulo: Hucitec; 1997. 220 p.

18. Organização Pan-Americana da Saúde. Manual de vacinas da América Latina. Madri: Euro RSCG Life Esquema; 2005. 620 p.

19. Secretaria de Estado da Saúde de São Paulo (BR). Norma técnica do programa de imunização. São Paulo: Centro de Vigilância Epidemiológica; 2008. 68 p.

20. Ozaki LMTR, Shimo AKK. O significado da vacina contra rubéola para as mulheres grávidas. Rev. LatinoAm. Enfermagem. 2007;15(4):529-35.

21. Rocha SMM, Nascimento LC, Lima RAG. Enfermagem pediátrica e abordagem da família: subsídios para o ensino de graduação. Rev. Latino-Am. Enfermagem. 2002;10(5):709-14.

22. Mello DF, Lima RAG, Scochi CGS. Health follow-up of children in poverty situation: between the routine and eventuality of daily care. Rev. Latino-Am. Enfermagem. 2007;15(Spe):820-7.
Received: Mar. $4^{\text {th }} 2010$ Accepted: Mar. $17^{\text {th }} 2011$ 